\title{
Understanding sexuality by rural elderly women
}

\author{
Compreensão da sexualidade por idosas de área rural \\ Comprensión de la sexualidad por ancianas de medio rural
}

\section{Nidiane Evans da Silva Cabral' ORCID: 0000-0001-6397-2411 \\ Claudia Feio da Maia Lima' ORCID: 0000-0002-4718-8683}

Maria da Conceição Costa Rivemales' ORCID: 0000-0001-7773-4772

Uilma Santos de Souza' ORCID: 0000-0002-0045-936X

Bárbara Martins Corrêa da Silva' ORCID: 0000-0001-5894-2162

'Universidade Federal do Recôncavo da Bahia. Santo Antônio de Jesus, Bahia, Brazil.

How to cite this article: Cabral NES, Lima CFM, Rivemales MCC, Souza US, Silva BBMC. Understanding sexuality by rural elderly women. Rev Bras Enferm. 2019;72(Suppl 2):147-52. doi: http://dx.doi.org/10.1590/0034-7167-2018-0385

\section{Corresponding Author:} Nidiane Evans da Silva Cabral E-mail: nidi.evans@gmail.com

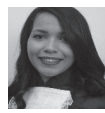

Submission: 06-10-2018

Approval: 07-19-2018

\section{ABSTRACT}

Objective: to understand the meaning of sexuality by rural elderly women. Method: a qualitative exploratory and descriptive research, carried out through interview at the home with 26 rural elderly women, aged between 60 and 69 years. The data were analyzed by the thematic content analysis technique of Bardin. Results: understanding sexuality is linked to the construction of sexual and/or loving relationship, and positive and negative factors that interfere with the exercise of sexuality: good relationship with the spouse, physical and mental benefits, chronological age, health problems, no spouse, sexual disinterest and fear of relating for fear or disappointment. Final considerations: there is a decline in the maintenance of sexuality linked to the end of the reproductive period, to the advancing age and the low social perspective that is common for rural elderly women.

Descriptors: Sexuality; Elderly; Women's Health; Rural Area; Basic Health Unit.

\section{RESUMO}

Objetivo: compreender o significado da sexualidade por idosas que vivem em área rural. Método: pesquisa de abordagem qualitativa, de caráter exploratório e descritivo, realizada por meio de entrevista no domicílio a 26 idosas de área rural, com idade entre 60 e 69 anos. Os dados foram analisados pela técnica de análise de conteúdo temática de Bardin. Resultados: a compreensão da sexualidade atrela-se à construção da relação sexual e/ou amorosa, e aos fatores positivos e negativos que interferem no exercício da sexualidade: bom relacionamento com o cônjuge, benefícios físicos e mentais, idade cronológica, problemas de saúde, ausência de cônjuge, desinteresse sexual e receio de se relacionar por medo ou decepção. Considerações finais: existe um declínio da manutenção da sexualidade, atrelado ao fim do período reprodutivo, ao avançar da idade e à baixa perspectiva social, comum para idosas em área rural.

Descritores: Sexualidade; Pessoa Idosa; Saúde da Mulher; Área Rural; Unidade Básica de Saúde.

\section{RESUMEN}

Objetivo: comprender el significado de la sexualidad por las ancianas que viven en el medio rural. Método: la investigación de abordaje cualitativo, de carácter exploratorio y descriptivo, realizada por medio de entrevista en el domicilio a 26 ancianas de medio rural, con edad entre 60 y 69 años. Los datos fueron analizados por la técnica de análisis de contenido temático de Bardin. Resultados: la comprensión de la sexualidad se atreve a la construcción de la relación sexual y/o amorosa, ya los factores positivos y negativos que interfieren en el ejercicio de la sexualidad: buena relación con el cónyuge, beneficios físicos y mentales, edad cronológica, problemas de salud, ausencia de cónyuge, desinterés sexual y temor a relacionarse por miedo o decepción. Consideraciones finales: existe un declive del mantenimiento de la sexualidad, vinculado al final del período reproductivo, al avanzar de la edad y la baja perspectiva social, común para ancianas en medio rural.

Descriptores: Sexualidad; Anciano; Salud de la Mujer; Medio Rural; Unidad Básica de Salud. 


\section{INTRODUCTION}

The world's fastest growing population group is the elderly. Women have stood out as the majority of the elderly population in Brazil, living, on average, 5 to 8 years older than men, which leads to the realization of the process of feminization of old age. With aging, there are many demands for care related to physical, psychic and social changes. In this period of life, the elderly experience loss, financial difficulties, lack of family support and presence of chronic and degenerative diseases ${ }^{(1)}$.

With the increase in the number of elderly people, the Family Health Strategy (FHS) becomes an ally to attend to health needs, making itself present in urban and rural areas. In rural areas, the diseases manifest themselves differently, influenced by environmental factors and the way of work ${ }^{(2)}$. Therefore, rural health should be designed and implemented to ensure the rights peculiar to rural life, with a rural development strategy ${ }^{(3)}$. The FHS should provide the means for elderly people to age with quality, taking care not only of the physical but also of other human dimensions (social, economic and emotional), in order to care for and embrace new themes relevant to the integral health of the subjects, such as sexuality ${ }^{(4-5)}$.

Sexuality is composed of human aspects, with innumerable forms of manifestation. In other words, it means a force that makes explicit the ability to unite people to pleasure/displeasure, desires, needs and life itself, experienced by thoughts, actions, fantasies, desires, doctrines, judgments, habits and conviviality ${ }^{(6)}$.

Women demonstrate their femininity through corporeality through sexuality. Physiological changes in old age influence the sexual response of the elderly, but it does not mean that they make them "asexual", without desires or incapable of feeling pleasure. Changes in the sexual function can lead them to the expression of sexuality with a new meaning and evidence of new possibilities, besides penetration ${ }^{(7)}$.

\section{OBJECTIVE}

To understand the meaning of sexuality by rural elderly women.

\section{METHOD}

\section{Ethical aspects}

There was approval by the Ethics and Research Committee (ERC) of the Universidade Federal do Recôncavo da Bahia, in compliance with the provisions of Resolution CNS (Brazilian Health Board) $466 / 2012^{(8)}$. The interviews began after the consent of the participants, through clarifications on the research and subsequent signing of the Free and Informed Consent Form (FICF). The anonymity was maintained and a pseudonym was given to each of the elderly participants, anticipated from the letter " $E$ " and an Arabic number in sequential order of collection.

\section{Type of study}

This is a cut of the Research Project submitted and approved for PIBIC 2017-2018, entitled:Compreensão de pessoas idosas deárea rural acerca da sexualidade no Município de Cruz das Almas-Ba, a qualitative approach, and an exploratory and descriptive character, aimed at the understanding of sexuality by rural women, linked to the FHS.

\section{Study setting and data source}

This study was carried out in the household of elderly women living in the District of Sapucaia, rural area of the Municipality of Cruz das Almas, Bahia State. Twenty-six elderly women enrolled in the Basic Health Unit (BHU) and identified with the support of the Community Health Agents (CHA). For inclusion in the research, the following criteria were established: age between 60 and 69 years; women; residing in the rural area of Sapucaia; be registered at the $\mathrm{BHU}$ that serves the aforementioned district; and be in regular care by the health team. The exclusion criterion was for elderly women with some type of cognitive impairment and/or difficulty in communication (auditory and verbal).

\section{Collection and organization of data}

Data collection took place between September 2017 and October 2017, through the completion of a questionnaire for socioeconomic and health identification, followed by a single and private semi-structured interview, previously scheduled and guided by the following question: what is the understanding that rural elderly women, from the Municipality of Cruz das Almas, Bahia State, have about sexuality?

\section{Data analysis}

The analytical procedure was based on the thematic content analysis technique ${ }^{(9)}$. The categories came from detailed transcripts of interviews recorded in digital media, followed by the exploratory pre-analysis of the material by readings and data organization for the treatment and interpretation phase of the findings. At the end, two categories emerged: Understanding of rural women about sexuality and Interference in the exercise of sexuality.

\section{RESULTS}

The profile of the elderly women in the study was between 60 and 69 years old, with a predominance of 60-64 years $(15=$ $57.69 \%)$. The majority were black $(19=73.07 \%)$, Catholic ( $17=$ $65.38 \%$ ), with incomplete Middle and Elementary school (22 $=84.61 \%)$, family income of a minimum wage $(19=73.07 \%)$, without employment relationship and still working in agriculture $(10=38.46 \%)$, married $(11=42.31 \%)$, number of children $<5(16$ $=61.53 \%)$ and living with first - degree relatives - children $(8=$ $30.76 \%)$. Most of them have a diagnosis of arterial hypertension $(10=38.46 \%)$, with regular use of losartan associated with other drugs $(11=42.31 \%)$, and usually seek medical attention for BHU $(16=61.53 \%)$. The associated health problems were: Dyslipidemias, Osteoporosis, Chagas Disease, Breast Cancer, Hypothyroidism, Anxiety Disorder and Diabetes Mellitus $(10=38.46 \%)$.

After a detailed analysis of the interviews, two thematic categories were established, based on different contents of understanding. In category 1 - Understanding of rural women about sexuality - there was a predominance of linking the term 
"sexuality" to the sexual act and, to a lesser extent, to affectivity and companionship. However, the importance to the elderly of caressing and companionship as a means of maintaining sexual intercourse and expressing their sexuality was perceived, even though with less intensity and expectations in old age.

What I understand is that we have sex, only! (Amaryllis E1)

It's sex, is not it? Between a man and a woman [...]. (Lavender E22)

[...] it's love and affection It is an act of being well, of being well with your partner, with your partner [...].For me, it is to give continuity to the love you have with your partner, even though in a different way. (Iris E8)

Through the discourses of the elderly, there was a decline in the practice of sexual intercourse, linked to the end of the reproductive period, that is, an idea of sexuality still very much linked to the act of procreation. The love relationship, at this stage of life, was identified in the data analyzed, but with a prominence for the noninterdependence of the current body condition. With the physiological changes of aging, there is a renewal of the practice of sexuality that detaches itself from the body but is capable of generating pleasure.

[...] I do not practice, no. I do not have a husband anymore, nor do I have more children at that age. (Primrose E14)

I think it's important, even with the changes we undergo [...].Today is not that you cannot live without, but it is important and we need to see other ways, because the body is not as before [...]. (Urze E18)

Category 2 - Interference in the exercise of sexuality - portrays the positive and negative interferences suffered in the exercise of sexuality by the elderly women related to the study. Regarding the positive conditions for the continuity of sexuality in old age, the testimonies revealed the perception about the physical and mental benefits of this practice and of a better experience, when there is loving relationship. Relaxation of the body, reduction of stress and feeling of being alive were described as a favorable effect in maintaining the exercise of sexuality.

It is important sexuality in the life of the human being, in matters of health, relaxation, mind [...], it leaves you more relaxed and calmer. (Magnolia E23)

[...] when someone flirt with us [laughs] we feel alive! We feel good [...], so when we get a compliment, an exchange of look, something like that, we feel like people are alive. (Lavender E22)

Another finding that emerged from the interviews, capable of benefiting the sexuality of the elderly women in the rural area, was the good relationship with the spouse or even the simple presence of a fixed partner for the maintenance of the sexual life. Otherwise, they affirmed a progressive decline in the maintenance of sexual desire and the practice of sexuality. Factors such as affection, kissing, hugging and feeling the partner, emphasizing the importance of living it in an integral and satisfactory way, and of perceiving the partner in the relationship as a subject that collaborates for the understanding, the companionship and the shared dialogue were also related the good relationship with the partner.

We get along, we talk, we love each other, we caress each other, we go out to church [...].We lean back, come slowly, meet, he hugs me [laughs]. (Urze E18)

I lived well and happily with my husband, he was a wonderful person [...] I separated because of death, if it were not for that, we would be together until today. We had sex with love, today I do not practice anymore. (Dianthus chinensis E3)

Among the negative interferences scored by the participants, chronological age emerged expressively as a limiting factor, reinforcing the idea of asexuality in old age, influenced by sociocultural reasons.

[...] because of age [...], at that age, girl, we forget even these things, did you know that? I am already 63, and he is 78 [...]. (Lavender E21)

Oh, it does not work, no! I do not like it and I do not want to anymore [...], I do not have the age anymore for this [...]. (Veronica E25)

The findings also revealed the fear of rural women in having new relationships, due to fear or amorous disappointment that directly interferes with the continuity of sexuality experiences. In the speeches, it was noticed that emotional frustrations experienced in the relation to two were able to mobilize them to give up the exercise of sexuality, for linking emotional conditions to the practice of sexuality.

To find a person, nowadays, is no longer finding anything worthwhile. So, for us to get a person, to end up complicating ourselves, not living well [...], then it is better for the person to live alone. In my point of view, the person alone goes wherever he wants, goes whenever he wants, the person does not worry [...]. (Lotus flower E06)

[...] there are things that are disappointment of life, that we do not like them anymore [...], I have had enough [...]. (Daisy E11)

Issues related to different health problems made up the statements of rural women as a negative factor for a practice of limited or non-existent sexuality.

The interference he's having now is because he's sick, so I'm not having it any more, like at that time he was healthy [...].The sick person, the illness has been interrupting the best moments [...]. He has a liver cirrhosis problem and it was something I got used to, that I know he's sick, I'm taking better care of his health [...]. (Dahlia E4)

He is sick, the disease has attacked and one side has been forgotten. I'm going to look for another one? No, I cannot! Even because of things are today [...].It was after 50 that he fell ill. I have not worried about this for some time now [...]. (Fennel E05)

Concerning the negative interferences for the maintenance of the sexuality of rural women, it was noticed that those without a partner (widowhood, divorce or marital status) understood that there was no more room for love life, living in silence and denying many times, desires. The decrease in interest in sexual 
activity and, consequently, the loss of intimate relationships, is directly related to the female widowhood.

[...] my husband died 5 years ago. [...] no, I do not want anything else, because God took my husband. [...]. (Lily E10)

Oh, my daughter, I tried, but it did not, because my husband died. I was a widow, I was young, I was renewed and then it kept going, the boys used to live crazy behind me, I still tried to see if it worked, but I did not give up. (Daffodil E12)

The lack of interest in sexuality appeared at various moments in the discourses of the elderly women in this research, negatively influencing the practice of sexuality, in general, linked to several factors, some of them narrated in the speeches collected.

Honestly, for my life, it has already mattered, but nowadays [...], for me, it does not exist anymore, it does not matter at all. I do not want anynobody, anynobody [...]. (Hydrangea E7)

I do not want to have anyone else in my life. I no longer want to have anything, to do nothing, because I'm alone, not wanting to date and I think I would not know how to seduce someone anymore [...]. (Salvia farinacea E24)

\section{DISCUSSION}

The testimonies analyzed show that the understanding of sexuality is based on the idea of sexual intercourse. This idea is built from youth, when sexuality was experienced from marriage, between the relationship man and woman, with purpose of reproduction, that is, with the idea of sexual intercourse between people, defined by the sexual practice itself ${ }^{(10)}$.

The understanding of sexuality as a love relationship is characterized by companionship, affection and friendship, feelings that contribute to the maintenance of intimacy, satisfaction and independence. With the advancing age, there is a change in the practice of sexuality, which is now based on love and companionship ${ }^{(11)}$, because for older people to experience sexuality, they have several positive and opportune points to express love, caress and affection ${ }^{(12)}$.

Sexuality involves intimate moments, with varied forms of pleasure and desire, in addition to the sexual act, embracing love, affection and complicity that are valued more than the sexual act itself. Even with aging, older women maintain their ability to love, exchange passionate glances, kisses and hugs, until the end of their lives ${ }^{(13)}$.

With the physiological changes of aging, there is a renewal of the practice of sexuality that detaches from the body, since it is possible to experience sexuality in old age in a satisfactory way, when the sexual act ceases to be the main source of pleasure and the caresses are highlighted. What counts is the willingness to experience other forms of pleasure(14).

It should be understood that aging is influenced by factors that directly or indirectly affect the behavior and sexual response of elderly women, whether they are biological, physiological, psychological, cultural, educational and/or marital relationship, regardless of age $^{(15)}$.
Elderly people assume that sexuality is important to their lives, that sexual activity on a regular basis promotes well-being to the body and mind, and contributes to the reduction of physical and psychological problems associated with the aging process ${ }^{(16)}$. Therefore, maintaining good interpersonal relationships in old age based on harmony, affection, love, sex and complicity, promotes a more satisfactory and healthy aging. These relationships allow a balance between senescence and mental and physical functions, which reinforces its therapeutic effect, including in the sexual and affective field ${ }^{(15)}$.

A good marital relationship or even the simple presence of a fixed partner, that enables the elderly woman to continue exercising her sexuality, is considered positive ${ }^{(7)}$. With a sexual partner, they manifest a desire to maintain sexual activity. Nonetheless, in his absence, there is a progressive decline in the maintenance of sexual desire and the general practice of sexuality ${ }^{(7)}$. Other factors also count for a good conjugal coexistence, such as affection, kissing, hugging and feeling the partner, emphasizing the importance of living it in an integral and satisfactory way, and of perceiving the partner in the relationship as a subject that collaborates for understanding, companionship and shared dialogue $\mathrm{e}^{(10)}$.

The context of the elderly woman's sexuality is marked by uniqueness, in which the cultural dimension is reinforced by the asexual stereotype, given the view that they are not attractive and capable of generating sexual interest for themselves and the other at this stage of life. Furthermore, the physiological and hormonal changes that occur in the aging female body mark the beginning of the decline in sexuality for many women. It is important to consider the influences caused by the self-image and self-esteem of eliciting elders of libido impairment, seduction capacity and femininity, being common the distorted idea of self and the creed of inability to exercise sexuality ${ }^{(15)}$.

Fearing social stigma for showing sexual interest in old age, older women sexually annul themselves ${ }^{(17)}$. The inadequate judgment of society condemns the experience of sexuality by the elderly, negatively influencing self-perception and self-management. It is worth emphasizing that today's older women have experienced a more expressive social and moral rigidity, leading them to look at age as a limiting factor for the exercise of sexuality. Sometimes the understanding of a phase of life characterized by the absence of joy, self-esteem and sense of closeness to death, assumes sexuality in old age as nonexistent ${ }^{(15)}$.

Elderly people find it difficult to maintain interest in the sex life by experiencing betrayal, hurt and resentment. On the other hand, there are elderly women who can overcome resentments and dislikes caused by traumas resulting from past affective-sexual experiences. Therefore, problems in amorous relationships caused by conflicts, unresolved grudges, anger and resentments, can influence, over the years and in an unfavorable way, the conviviality of the couple, 'cooling'the sexual relationship ${ }^{(18)}$. A conjugal relationship, in order to be healthy, requires pleasant and respectful affective-sexual intercourse, otherwise, it tends to failure and unhappiness ${ }^{(19)}$.

Issues related to different health problems also included the statements of elderly women in rural areas, presenting as a reason for a practice of limited or non-existent sexuality. The illness in the companion or in the elderly woman diminishes or annuls the sexual practice, especially, when it is related to the 
old person of the male sex by the commitment of the masculine sexual resourcefulness. It is valid to evaluate the consequences of comorbidities in elderly women and their spouses ${ }^{(7)}$.

Over the years, there is a decrease in sexual practice caused by physiological and pathological changes, responsible for the difficulty of the most intimate relationship. Health is a variable that influences the interest in the sexual activity of the elderly. In addition to the physiological changes inherent in the aging process, some diseases may interfere with the experience of sexuality ${ }^{(7,15-16)}$. These comorbidities, which mostly have a character of chronicity, end up negatively impacting sexual activity, by interfering with sexual desire and performance. With them, the use of different drug classes, whose possible adverse effects depress sexual activity ${ }^{(13,15)}$.

The sexuality of the elderly woman is linked to conjugality. When they see themselves alone, after the loss of their spouse, many find it difficult to maintain a prolonged relationship with a new partner, because they believe that the relationship is of material interest or because they maintain equal expectations of the marital relationship, occurring frustrations ${ }^{(18,20)}$. Several elderly widows or divorcees, and those who do not have active sexual partners, experience a decrease or absence of sexual activity. Moreover, there is a greater proportion of older women than men, evidencing the feminization of old age ${ }^{(21)}$. They tend to live alone, while they, under similar conditions, choose to experience new relationships, including new marriages with younger women ${ }^{(13)}$.

The decrease in hormonal levels and the stages that lead to female aging, stimulate disinterest for sexuality, with consequent decrease in sexual activity. However, non-hormonal issues are also related to loss of interest, such as emotional state, quality of relationships and environment ${ }^{(16)}$.

Feelings of fear of failing sexually, incapacity and personal devaluation can cause the interruption and the abandonment of sexuality. The lack of sexual interest may be related to low self-esteem, absence of a partner and suffered bodily alterations, generating a process of interruption of new affective-sexual experiences and carelessness with regard to the exercise of sexuality in daily life $\mathrm{e}^{(10,15)}$.

\section{Study limitations}

The research presented had some limitations for a broader development. Initially, there were obstacles to access to the data in the medical records, in relation to sociodemographic and health information of the health team. Another difficulty was related to the geographic issues due to the distanced location of some households and the commuting transportation, which was restricted in schedules. Finally, another difficulty presented itself in the profile of the elderly participants, regarding the opening for communication about the theme, considering the social constraints pointed out by the research.

\section{Contributions to Health and Nursing}

The contribution of this production to nursing and the health team, especially the $\mathrm{BHU}$, returns to the clear identification of the non-approach to the theme "sexuality" in the planning of health promotion and prevention actions. It also reiterated the need to include it in order to provide comprehensive care to the elderly, female and rural population as a means of demystifying the culture of female asexuality in old age and naturalize the life dimension of women who grow older in differentiated settings, such as rural.

\section{FINAL CONSIDERATIONS}

The understanding of rural women about sexuality is very much based on the sexual act and the existence of the partner for this performance. Moreover, the sexuality of these women followed a flow common to others, which even in settings and conditions different from those studied here, show progressive disinterest for the maintenance of the sexuality exercise with the passage of the reproductive period and the advancement of the age.

The elderly of the research understand that the way of experiencing sexuality differs from that of youth, but there is also an emphasis on the importance of affectivity, permeating relationship and dialogue as a means of conjugal harmony. Chronological age and the very conditions in which they often grow old, with the development of chronic diseases, coupled with low income, social restriction and low family support and/or health service, do not offer a possibility of envisaging a continued practice of sexuality with a new meaning.

Growing old and having the reference of sexuality linked to the physiology of the body and the affective-sexual relationship experienced throughout life will define, for many, the discontinuity of sexual practice. Self-esteem, self-care and continuous dialogue may not work as a path of a new meaning, precisely because there is no approach of this dimension in the family and health services.

Geographical conditions of these women contribute very little to a healthcare and nursing process. The culture and habits to which the elderly women are conditioned can make them vulnerable to the satisfaction of their needs in the sexual field. There is an urgent need to pay for care by including the theme "sexuality" of aging people as a means of dialogue, care and an expanded professional vision.

\section{FUNDING}

The present study was funded through the National Council for Scientific and Technological Development - CNPQ (Conselho Nacional de Desenvolvimento Científico e Tecnológico)'s scholarship for scientific initiation - PIBIC.

\section{REFERENCES}

1. Sales J, Jr F, Vieira C, Figueiredo M, Ferreira C. Feminização da idade velha e sua interface com a depressão: revisão integrativa. Rev Enferm UFPE [Internet]. 2016[cited 2018 Apr 08];10(5):1840-6. Available from: https://doi.org/10.5205/1981-8963-v10i5a13564p1840-1846-2016

2. Silva EF, Paniz VMV, Laste Gabriela T, Silva IL. Prevalência de morbidade e sintomas em idosos: um estudo comparativo entre as zonas 
rurais e urbanas. Ciênc Saúde Coletiva [Internet]. 2013 [cited 2018 May 23];18(4):1029-40. Available from: http://dx.doi.org/10.1590/ S1413-81232013000400016

3. Dimpério M, Zeni M, Valandro J, Hillig C. Percepção da saúde pública em uma comunidade na zona rural de Santa Rosa - Rio Grande Do Sul, Brasil [Internet]. III Jornada de Extensión del Mercosur. Rio Grande do Sul: UNICEN; 2014 [cited 2018 May 23]. Available from: http://www. extension.unicen.edu.ar/web/jem2014/ponencias/

4. Sousa LG, Antunes M. Enfermagem e a saúde do idoso residente em zona rural [Dissertação] [Internet]. Universidade Federal de Minas Gerais; Faculdade de Medicina. Núcleo de Educação em Saúde Coletiva. 2014 [cited 2018 May 23]. 36 p. Available from: https://www. nescon.medicina.ufmg.br/biblioteca/registro/referencia/0000004273

5. Castro SFF, Nascimento BG, Soares SD, Barros Jr FO, Sousa CMM, Lago EC. Sexualidade na terceira idade - a percepção do enfermeiro da estratégia saúde da família. Rev Enferm UFPE [Internet]. 2013 [cited 2018 Apr 15];7(10):5907-14. Available from: https://doi. org/10.5205/1981-8963-v7i10a12216p5907-5914-2013

6. Ministério da Saúde (BR). Secretaria de Atenção à Saúde. Departamento de Atenção Básica. Saúde sexual e Saúde Reprodutiva. Brasília: Ministério da Saúde, 2013. Available from: http://bvsms.saude.gov.br/bvs/publicacoes/saude_sexual_saude_reprodutiva.pdf

7. Alencar DL, Marques APO, Leal MCC, Vieira JCM. Fatores que interferem na sexualidade de idosos: uma revisão integrativa. Ciênc Saúde Coletiva [Internet]. 2014[cited 2018 May 23];19(8):3533-42. Available from: http://dx.doi.org/10.1590/1413-81232014198.12092013

8. Ministério da Saúde (BR). Resolução no 466, de 12 de Dezembro de 2012. Aprova [...] diretrizes e normas regulamentadoras de pesquisa envolvendo seres humanos. Conselho Nacional de Saúde, Brasília, DF; 12 dez. 2012. p. 2. Available from: http://bvsms.saude.gov.br/bvs/ saudelegis/cns/2013/res0466_12_12_2012.html

9. Bardin L. Análise de conteúdo. $6^{\mathrm{a}}$ ed. Reto LA, Pinheiro A, tradutor. São Paulo: Livraria Martins Fontes; 2011, 280 p.

10. Uchôa YS, Costa DCA, Silva Jr IAP, Silva STSE, Freitas WMTM, Soares SCS. A sexualidade sob o olhar da pessoa idosa. Rev Bras Geriatr Gerontol[Internet]. 2016 [cited 2018 May 23];19(6):939-49. Available from: http://dx.doi.org/10.1590/1981-22562016019.150189

11. Lima CFM, Caldas CP, Santos I, Trote LAC, Silva BMC. Cuidado terapêutico de enfermagem: transição na sexualidade do cônjuge cuidador do idoso. Rev Bras Enferm[Internet]. 2017[cited 2018 May 23];70(4):673-81. Available from: http://dx.doi.org/10.1590/0034-7167-2016-0256

12. Santos M, Nunes R, Cruz G, Souza M, Barbosa R, Lima E, et al. Percepções e Vivências de Sénior sobre a Sexualidade. Alman Multidisc Pesqui[Internet]. 2017 [cited 2017 Dec 07];1(1):25-36. Available from: http://publicacoes.unigranrio.com.br/index.php/amp/article/ view/4317/2337

13. Nery V, Valença T. Sexo e sexualidade no processo de envelhecimento. C\&D-Rev Eletr Fainor [Internet]. 2014[cited 2018 Feb 21];7(2):20-32. Available from: http://srv02.fainor.com.br/revista/index.php/memorias/article/view/304/190

14. Vieira K, Coutinho M, Saraiva E. A Sexualidade na velhice: representações sociais de idosos frequentadores de um grupo de convivência. Psicol Cienc Prof [Internet]. 2016 [cited 2018 Feb 23];36(1):196-209. Available from: http://www.scielo.br/pdf/pcp/v36n1/1982-3703pcp-36-1-0196.pdf

15. Vieira S, Hassamo V, Branco V, Vilelas J. A vivência da sexualidade saudável nos idosos: o contributo do enfermeiro. Rev Ciênc Saúde ESSCVP [Internet]. 2014l [cited 2018 Mar 22];6:35-45. Available from: http://www.salutisscientia.esscvp.eu/Site/download.aspx?artigoid=31177

16. Oliveira L, Baía R, Delgado A, Vieira K, Lucena A. Sexualidade e envelhecimento: avaliação do perfil sexual de idosos não institucionalizados. Rev Ciênc Saúde Nova Esperança [Internet]. 2015 [cited 2018 May 15];13(2):42-50. Available from: http://www.facene.com.br/wp-content/ uploads/2010/11/SEXUALIDADE-E-ENVELHECIMENTO-PRONTO.pdf

17. Souza M, Marcon SS, Bueno SMV, Carreira L, Baldissera VDA. A vivência da sexualidade por idosas viúvas e suas percepções quanto à opinião dos familiares a respeito. Saude Soc [Internet]. 2015 [cited 2018 May 10];24(3):936-44. Available from: http://www.scielo.br/pdf/sausoc/ v24n3/0104-1290-sausoc-24-03-00936.pdf

18. Leão A, Sassaki Y. Um retrato da sexualidade da mulher idosa no conto "mas vai chover", de Clarice Lispector. Rev Graphos [Internet]. 2016 [cited 2018 Mar 16];18(1):4-12. Available from: http://periodicos.ufpb.br/ojs/index.php/graphos/article/view/30589/16119

19. Catapan N, Brito R, Cavalcanti P, Pereira D, Torres N. Compreendendo a senescência na ótica da sexualidade feminina. Ciênc Praxis [Internet]. 2014 [cited 2018 Mar 16];7(14):19-24. Available from: http://revista.uemg.br/index.php/praxys/article/view/2142/1134

20. Fleury H, Abdo C. Sexualidade da mulher idosa. Diagn Tratamento [Internet]. 2015 [cited 2018 Feb 05];20(3):117-20. Available from: http:// files.bvs.br/upload/S/1413-9979/2015/v20n3/a4902.pdf

21. Figueiredo $M$, Silva $M$, Machado S, Silva S. Sexualidade na terceira idade: a prática profissional da educação em saúde na estratégia de saúde da família[Internet]. Editora Realize. 2017 [cited 2018 Feb 22]. Available from: https://editorarealize.com.br/revistas/conbracis/trabalhos/ TRABALHO_EV071_MD4_SA4_ID1543_12052017195433.pdf 